\title{
Boys versus girls' educational performance: Empirical evidences from global north and global south
}

\author{
Raza Ullah* and Hazir Ullah
}

Department of Sociology, International Islamic University, Islamabad, Pakistan.

Accepted 25 September, 2019

\begin{abstract}
Young girls have been dominating boys in terms of educational performance across the globe. This is a very interesting and remarkable shift observed in the global north as well as in the global south. This review paper seeks to give a succinct picture of gender differences in educational performance in the sociocultural context of various societies across the globe. Thus, the paper is based on the key findings of different studies, both from global north and global south. The study findings highlight the gender reverse change in education across the world. It also highlights the reasons of boys' underperformance and girls' outperformance in different societies. Skimming a number studies, attests that boys are being dominated by girls in educational performance, both in the developed as well as developing countries.
\end{abstract}

Keywords: Gender, educational performance, gender reverse change.

*Corresponding author. Email: razaullahkhan01@gmail.com.

\section{INTRODUCTION}

Gender is one of the systematic sources of inequality in education (Burgess and Parker, 1997). Until recently, girls fell behind boys in education. Girls' access to education was limited and discriminatory. Education was considered the prerogative of men/boys (Ullah, 2013). Girls were disadvantaged in education as they received less teachers' attention and limited access to higher education. Such attitude resulted in discrimination between boys and girls forcing girls to leave school early than boys and advantaged boys to continue schooling and perform better than girls. Nevertheless, data from 1990 s and 2000 continue to suggest a dramatic change in education in the form of girls' outperformance. Girls are outperforming boys in education irrespective of the global north and south (Burgess and Parker, 1997; Parson and Ozaki, 2018). A number of studies concluded that girls' outperformance and boys' underperformance in education appears to be a global trend. This paper, after skimming and sharing the findings of many studies from different socio-cultural backgrounds across the world, asserts that the position is rather more complex than the simple statement 'girls are now outperforming boys'. We argue that more and more studies in different contexts need to be carried out to prove the ongoing trend as established fact.

The late $20^{\text {th }}$ century has seen a gender reversal change in education in the form of girls' outperformance and boys' underachievement. A considerable number of studies and debates have been carried out on this reversal change in education in global north (Gouleta, 2015; McDowell, 2000; Mburu, 2016; Peter et al., 2005; Bae et al., 2000:2; Hung et al., 2012; Peter et al., 2005; Bae et al., 2000) and global south (Datta, 2014; Good et al., 2003; Twist et al., 2004). The discourse of boys' outperformance in education that once existed has now been shifted to girls' outperformance. Younger and Warrington (2007) assert that this change has been evolved from the boys' underachievement and girls' higher achievement in education. It is reinforced by the findings a recent study conducted by Parson and Ozaki (2018). According to the findings, girls are outperforming boys in education. They concluded that the performance gap, favoring girls, is significantly increasing particularly in secondary education. It is now an established fact that boys now not only fall behind in terms of educational achievement at school level (Minello and Blossfeld, 2017; Lai, 2010; Jürges and Schneider, 2011; Warrington et al., 2003; Burns and Bracey, 2001) but also at the colleges 
and universities (Jacob, 2002; Buchmann and DiPrete, 2006; Conger and Long, 2010; Taylor, 2005; Ewert, 2012). Thus, girls outperform boys in education and the gap between boys and girls educational attainment rises with every level and grade (Gorard et al., 2001; Buchmann and DiPrete, 2006).

\section{MATERIALS AND METHODS}

We deem it important to mention here that this is a review paper and does not include meta-analysis. Therefore, methodology section may not be outlined as we do it for primary data analysis. Nevertheless, we adopted systematic approach and criteria for the selection of different studies. We also had vivid criteria for considering studies for review. For instance, we focused on studies carried out on girls- outperformance and boys underachieving in education. For this, we used well known online research database related to gender reversal change in education. The online databases are: a) Eric education, Science direct, Sciverse scopus and Google scholar. We selected these databases as these were accessible. We kept reviewing research articles, using the mentioned online database software until reaching the point of saturation. We reached the point of saturation by skimming 49 research studies. The authenticity of the references of these articles was ensured by querying Google scholars.

\section{REVIEW RESULTS}

A brief overview of the research findings in the global north is presented here to substantiate the argument.

\section{Boys versus girls' educational performance in the developed world}

Many studies across various societies in the global north have revealed that girl students have made worth gains in all realms of education and outperformed boy students. Studies across the developed world conclude that boys have been outperformed by girls in education at school, college and university level (McDowell, 2000; Tshabalala and Ncube, 2016). Similarly, Hung et al. (2012) argues that female students in United Kingdom have outperformed boys in education, especially at secondary and higher secondary levels. He further explained that girls have secured good grades than boys at school, college and even at university levels. It is also asserted that girls in United State of America are constantly performing better than boys in terms of educational achievement. Peter et al.'s (2005) study of the American universities revealed that girls are securing good grades at school and college levels. Similarly, in the United
States girls outperform boys not only at school and college level but they are outperforming boys at university. A recent study, commissioned by the United States Congress, concluded that girls are doing well than boys in school and college (Bae et al., 2000). In Japan, there are ample evidences that girls are outperforming boys in education at both secondary and higher secondary level. Morita et al. (2016) asserted that academic performance and achievement in education is constantly high among female students in Japan. They concluded and argued that outperformance of girls and underachievement of boys in education is not limited to school but encompass college and university. In Australia, female students outperform male students in education at school and college level. Adler et al. (1992) highlighted that female students were found to be more serious and doing well in education than male students. Similarly, a study conducted by Whitney and Smith (1993) revealed that boys are performing worse than girls at primary, middle, secondary and higher secondary level. In Germany, female students are constantly showing good results and securing good grades than male students at every education level. As reinforced by Weiler (1991) that female students have been dominated male students in German schools, colleges and universities in terms of grades. Further, by Allen (1992) that German female students have outperformed males not only at college and school level but also in higher education in terms of grades and results. The case of French girls is not different. In France, girls are securing good grades and outperforming boys in education. In France, female students are constantly outdoing boys in secondary and higher secondary education (MacLeod, 2018). He further asserted that the gap in academic performance favoring girls is significantly increasing with each passing year. McDowell and Ray (2000) in their study asserted that in the United Kingdom (UK) girls outperforming boys at levels of education. Similar findings have also been discussed by Glennerster (2002). $\mathrm{He}$ states that female students are doing well not only at school and college level but they are outclassing male students on a slight margin at university level. In summary, it can be argued that girls' outperformance and boys' underperformance in education have become an established fact in the developed world.

\section{Boys versus girls' educational performance in the developing world}

The trend of girls' outperformance in education is not limited to the developed world but has become a norm in the developing world as well. We deem it important to mention here that the status of boys and girls education in developing countries is different than developed countries, that is, majority of the world illiterate are in the developing countries. Developing countries have their 
own cultural contexts which are entirely different from the industrialized countries. In developing countries, access to education, especially for young girls, is not widespread. Different cultural and social contexts allow and provide different access to education in developed and developing countries. Despite of these differences and challenges in the way of women, girls are still performing better than boys (Grant and Behrman, 2010; Mensah and Kiernan, 2010; McDonald et al., 2011).

A recent study conducted by Datta (2014) on Kenyan society revealed that girl students have performed better than male students and secured good grades. Likewise, the findings of the study conducted by Kabeer (2005) in Zimbabwe, revealed that girls have outclassed boys in terms of education achievement at both school and college level. In Thailand, a similar reversal change has been observed at the school and college levels. In case of Thailand, the similar reversal change has been observed at both school and college levels. In India, the gender gap in education in favor of girls has been observed by the early 2000 . Natta et al. in their study of Indian society concluded that girls are showing good results at all level in education. They further, asserted that this gap is wider in urban centres where boys are lagging behind, especially at the school and college levels.

\section{Boys versus girls' educational performance in the Muslim world}

The gender reverse change in education has also been observed in Muslim countries. In Turkey, female students have excelled and performed better than male students in terms of educational attainment. Boys have been lagged behind by girls in terms of educational performances, especially at the school and college level. Yenilmez (2016) asserts, female students are often found to smash male students in secondary and higher secondary education. He further added that females' students have secured good grades at school and higher secondary school examinations (Yenilmez, 2016). In Malaysia, the same trend has been observed in educational institutions. Female students are doing well at all levels in education. According to Malaysian Ministry of Education (2000), female have shown good results with great consistency in Science, English, Malay and even Mathematics. A study conducted by Goolamally and Ahmad (2010) reveals that in Malaysia girls are performing well than boys in primary, secondary and higher secondary examinations in all subjects. The findings of the same study further show that boys poor performance grows with the course of time with huge disparity, especially in secondary and higher secondary education. According to the findings of the Ministry of Science, Research and Technology of the Islamic Republic of Iran, the performance of girls was found better in the competitive examination. In the competitive national college entrance examination, 51 percent females and 49 percent male qualified the exam. Similarly, Twist et al. (2004) asserted that girls outperformed boys in some Arab specking countries i.e. Arab Emirates, Morocco, Saudi Arabia, Qatar and Oman. The study conducted by Rahman (2005) revealed that female students in Bangladesh, especially at the school and college levels, shown good results as compared to male students. Similarly, the same trend has been registered by Yenilmez (2016) in his recent study Yenilmez asserted that the top position belonged to girl students at school and college levels.

\section{Factors of girls' outperformance and boys' underperformance in education across the globe}

In case of developed countries, girls outperform boys in education for a number of factors. For instance, in the context of United States of America, the role of parents is significant factor in the outperformance of their female children. As pointed out by Durden and Ellis (1995) that parents' education achievement is an important contributing factor to their female children education. Arellano and Padilla (1996) agreeing with Durden and Ellis, girls whose parents are educated, do well in education. Similarly, in Canada, United Kingdom and Australia boys' underachievement in education is largely linked with the authoritarian approach for them to be taught (Stormquist, 2007; Younger and Cobbett, 2014). In England, findings of a survey of 137000 parents and 280000 students in 500 secondary schools found that parents have greater educational aspiration for their daughters (Derby, 2007; Deary et al., 2007; Yenilmez, 2016). In Northern Ireland, boys' underachievement in education is due to their anti-school and non-serious behavior. As posited by Gallagher (1997) that the positive attitudes of girls towards schools, results in their outperformance in education and make them distinctive from boys in educational achievement. Gallagher goes on and suggests a number of factors including lack of male teachers, gender stereotyping by teachers, assessment favoring girls, boys rejecting authority and girls friendly and conducive environment are contributing factors in boys underperformance in England, Scotland and New Zealand. As Wilce (2007) pointed out that that children in the age group 7 to 11 had never have a male teacher. Bawden (2007) goes one step ahead and stated that feminization of teaching profession at school level has led to lack of male role model which adversely affects boyseducational performance especially at school level. One of the authors of this study is conducting research on the reasons of boys' underperformance in Pakistan.

A considerable number of studies in the developing countries encompass a range of reasons of girls' outperformance and boys' underachievement in education. Brown et al. (2010) argues that in Mongolia 
boys' underachievement in education has greatly associated with their personal freedom and higher status in family which spoil them. Alanen and Mayall (2001) further added that in Mongolia such situations in the long run result rebellious behavior among boys who disobey their teacher in the school, which in return, affect their studies badly. In Mongolia, family and cultural beliefs are favoring girls' education. Mongolia has traditional preferences for educating females. As discussed by Undarya and Enkhjargal (2011) that as in Mongolia, girls are not living with their parents for long time and thus the tradition has been to impart them education to ensure their future. A number of studies reported that boys' underachievement in Mongolia, Philippine and Thailand are due to their engagement in socio-economic activities (Dunne et al., 2005; Jha and Kelleher, 2006; Jha et al., 2012). For instance, poverty is one of the main factors in the way of boys' underperformance in education in Philippine. Along with their schooling boys perform labour work to assist their parents in fulfilling the needs of their family. They are helping in the family economy at a very early age Reimer (2012) assert that male child engages in various labour forces which badly affect their educational achievement. Similarly, in Philippine parental role is very important in the educational achievement of their children. Parents' check and balance upon children significantly affect the educational performance of their children (Rojiani, 2017; Spera et al., 2009). Ogbu (2003) claims that the absence of parents, especially the father being out country/city for job, affects the boys education in many ways i.e. young boys do not care for their study and indulge in useless activities which, in turn, adversely affect their educational achievement.

\section{CONCLUSION}

The overall conclusion that we reach from the findings of many studies across different societies is that there is a vivid trend of girls' outperformance and boys' underperformance in education across the world. The review also highlights that girls are outperforming not only at the school and college levels, but also in higher education. However, the position is rather more complex than the simple statement 'girls are now outperforming boys' as the factors of girls' outperformance and boys' underachievement vary from society to society and even within a society. Thus, this study asserts that the current trend needs to be examined in different socio-economic contexts and across discipline as it has been argued that boys do slightly better in science, especially mathematics (Arnot et al., 1998). It will not be a sweeping statement to argue that the findings of existing studies have challenged the biological and brain differences argument: girls are weaker and less intelligent and therefore lag behind boys in education. These findings suggest that girls can be as good in education as boys if they provided get opportunities like boys to prove themselves.

\section{Disclosure statement}

The author(s) declare no potential conflicts of interest.

\section{REFERENCES}

Adler, P. A., Kless, S. J., and Adler, P. (1992). Socialization to gender roles: Popularity among elementary school boys and girls. Sociology of Education, 65(3): 169-187.

Alanen, L., and Mayall, B. (Eds.). (2001). Conceptualizing child-adult relations. Psychology Press.

Allen, W. (1992). The color of success: African-American college student outcomes at predominantly white and historically black public colleges and universities. Harvard Educational Review, 62(1): 26-45.

Arellano, A. R., and Padilla, A. M. (1996). Academic invulnerability among a select group of Latino university students. Hispanic Journal of Behavioral Sciences, 18(4): 485-507.

Arnot, M., Gray, J., James, M., Rudduck, J., and Duveen, G. (1998). Recent research on gender and educational performance.

Bae, Y., Choy, S., Geddes, C., Sable, J., and Snyder, T. (2000). Trends in Educational Equity of Girls \& Women. ED Pubs, PO Box 1398, Jessup, MD 20794-1398.

Bawden, A. (2007). Missing male. In The Guardian, July $31^{\text {st }}$

Brown, P., Lauder, H., and Ashton, D. (2010). The global auction: The broken promises of education, jobs, and incomes. Oxford University Press.

Buchmann, C., and DiPrete, T. A. (2006). The growing female advantage in college completion: The role of family background and academic achievement. American Sociological Review, 71(4): 515541.

Burns, J., and Bracey, P. (2001). Boys' underachievement: issues, challenges and possible ways forward. Westminster Studies in Education, 24(2): 155-166.

Conger, D., and Long, M. C. (2010). Why are men falling behind? Gender gaps in college performance and persistence. The Annals of the American Academy of Political and Social Science, 627(1): 184214.

Datta, P. (2014). Self-concept and vision impairment: A review. British Journal of Visual Impairment, 32(3): 200-210.

Deary, I. J., Strand, S., Smith, P., and Fernandes, C. (2007). Intelligence and educational achievement. Intelligence, 35(1): 13-21.

Derby, J. (2007). Children and power in Mexican transnational families. Journal of Marriage and Family, 69(4): 1050-1064.

Dunne, M., Leach, F., Chilisa, B., Maundeni, T., Tabulawa, R., Kutor, N., Asamoah, A. (2005). Gendered School Experiences: the impact on retention and achievement in Botswana and Ghana. London: DfID.

Durden, G. C., and Ellis, L. V. (1995). The effects of attendance on student learning in principles of economics. The American Economic Review, 85(2): 343-346.

Ewert, S. (2012). Fewer diplomas for men: The influence of college experiences on the gender gap in college graduation. The Journal of Higher Education, 83(6): 824-850.

Gallagher, A. M. (1997). Educational achievement and gender: A review of research evidence on the apparent underachievement of boys. Department of Education, Northern Ireland.

Goolamally, N., and Ahmad, J. (2010). Boys do poorly in schools: The Malaysian story. Unpublished Manuscript.

Gorard, S., Rees, G., and Salisbury, J. (1999). Reappraising the apparent underachievement of boys at school. Gender and Education, 11(4): 441-454.

Gorard, S., Rees, G., and Salisbury, J. (2001). Investigating the patterns of differential attainment of boys and girls at school. British Educational Research Journal, 27(2): 125-139.

Hung, A., Yoong, J., and Brown, E. (2012). Empowering women through financial awareness and education. OECD Working Papers on Finance, Insurance and Private Pensions, (14), 1.

Jacob, B. A. (2002). Where the boys aren't: Non-cognitive skills, returns to school and the gender gap in higher education. Economics of 
Education Review, 21(6): 589-598.

Jha, J., and Kelleher, F. (2006). Boys' Underachievement in Education: An exploration in selected commonwealth countries. Commonwealth of Learning (COL).

Jha, J., Bakshi, S., and Faria, E. M. (2012). Understanding and challenging boys' disadvantage in secondary education in developing countries. Background paper for EFA Global Monitoring Report.

Jürges, H., and Schneider, K. (2011). Why young boys stumble: Early tracking, age and gender bias in the German school system. German Economic Review, 12(4): 371-394.

Kabeer, N. (2005). Gender equality and women's empowerment: A critical analysis of the third millennium development goal 1. Gender and Development, 13(1): 13-24.

Lai, F. (2010). Are boys left behind? The evolution of the gender achievement gap in Beijing's middle schools. Economics of Education Review, 29(3): 383-399.

McDowell, L. (2000). The trouble with men? Young people, gender transformations and the crisis of masculinity. International Journal of Urban and Regional Research, 24(1): 201-209.

Mickelson, R. A. (1989). Why does Jane read and write so well? The anomaly of women's achievement. Sociology of Education, 62(1): 4763.

Ogbu, J. U. (2003). Black American students in an affluent suburb: A study of academic disengagement. Routledge.

Peter, K., Horn, L., and Carroll, C. D. (2005). Gender differences in participation and completion of undergraduate education and how they have changed over time (pp. 1-67). National Center for Education Statistics, US Department of Education, Institute of Education Sciences.

Rahman, S. (2005). Orientations and motivation in English language learning: A study of Bangladeshi students at undergraduate level. Asian EFL Journal, 7(1): 29-55.

Reimer, J. K. (2012). Local negotiation of globalised educational discourses: the case of child friendly schools in rural Cambodia

Spera, C., Wentzel, K. R., and Matto, H. C. (2009). Parental aspirations for their children's educational attainment: Relations to ethnicity, parental education, children's academic performance, and parental perceptions of school climate. Journal of Youth and Adolescence, 38(8): 1140-1152.

Steele, C. M. (1997). A threat in the air: How stereotypes shape intellectual identity and performance. American Psychologist, 52(6): 613-629.

Stromquist, N. P. (2007). The gender socialization process in schools: A cross-national comparison. Background paper prepared for the Education for All Global Monitoring Report 2008 Education for All by 2015: will we make it.

Taylor, M. (2005). University gender gap widens as women increase their lead. The Guardian [British newspaper], 27th January. Retrieved from http://www.guardian.co.uk/uk/2005/jan/27/highereducation. students.

Twist, L., Gnaldi, M., Schagen, I., and Morrison, J. (2004). Good readers but at a cost? Attitudes to reading in England. Journal of Research in Reading, 27(4): 387-400.
Warrington, M., Younger, M., and McLellan, R. (2003). 'Underachieving boys' in English primary schools? Curriculum Journal, 14(2): 139-156.

Weiler, K. (1991). Freire and a feminist pedagogy of difference. Harvard Educational Review, 61(4): 449-475.

Whitney, I., and Smith, P. K. (1993). A survey of the nature and extent of bullying in junior middle and secondary schools. Educational Research, 35(1): 3-25.

Wilce, H. (2007, July). Complex tales of the males. TES.

Yenilmez, M. I. (2016). Women in academia in Turkey: Challenges and opportunities. Çanakkale Onsekiz Mart Üniversitesi Yönetim Bilimleri Dergisi, 14(28): 2.

Younger, M., and Cobbett, M. (2014). Gendered perceptions of schooling: Classroom dynamics and inequalities within four Caribbean secondary schools. Educational Review, 66(1): 1-21.

Younger, M., and Warrington, M. (2007). Closing the gender gap? Issues of gender equity in English secondary schools. Discourse: Studies in the Cultural Politics of Education, 28(2): 219-242.

Citation: Ullah, R., and Ullah, H. (2019). Boys versus girls educational performance: Empirical evidences from global north and global south. African Educational Research Journal, 7(4): 163167. 